Article

\title{
Willingness to Adopt Biochar in Agriculture: The Producer's Perspective
}

\author{
Agnieszka E. Latawiec 1,2,3,4,* , Jolanta B. Królczyk ${ }^{5}$, Maciej Kuboń ${ }^{3}$, Katarzyna Szwedziak ${ }^{6}$ \\ Adam Drosik ${ }^{7}$, Ewa Polańczyk ${ }^{6}$, Katarzyna Grotkiewicz ${ }^{3}$ and Bernardo B. N. Strassburg ${ }^{1,2}$ \\ 1 Rio Conservation and Sustainability Science Centre, Department of Geography and the Environment, \\ Pontifícia Universidade Católica, 22453-900 Rio de Janeiro, Brazil; b.strassburg@iis-rio.org \\ 2 International Institute for Sustainability, Estrada Dona Castorina 124, 22460-320 Rio de Janeiro, Brazil \\ 3 Faculty of Production and Power Engineering, Institute of Agricultural Engineering and Informatics, \\ University of Agriculture in Kraków, Balicka 116B, 30-149 Kraków, Poland; \\ maciej.kubon@ur.krakow.pl (M.K.); katarzyna.grotkiewicz@ur.krakow.pl (K.G.) \\ 4 School of Environmental Science, University of East Anglia, Norwich NR4 7TJ, UK \\ 5 Department of Manufacturing Engineering and Automation, Opole University of Technology, \\ Faculty of Mechanical Engineering, Mikołajczyka 5, 45-271 Opole, Poland; j.krolczyk@po.opole.pl \\ 6 Opole University of Technology, Department of Production Engineering and Logistics, Luboszycka 5, \\ 45-036 Opole, Poland; k.szwedziak@po.opole.pl (K.S.); e.polanczyk@po.opole.pl (E.P.) \\ 7 Department of Social Science, University of Opole, Katowicka 89, 45-061 Opole, Poland; \\ adrosik@uni.opole.pl \\ * Correspondence: a.latawiec@iis-rio.org or alatawiec@gmail.com
}

Academic Editor: Sanzidur Rahman

Received: 5 March 2017; Accepted: 8 April 2017; Published: 24 April 2017

\begin{abstract}
Most research on biochar has focused either on the mechanistic or the biophysical aspects, and there has been relatively little research into the social applicability and acceptance of biochar as a soil enhancer in agriculture. However, whether to adopt biochar in their practice is ultimately the farmers' decision, and their willingness to do so is crucial. Here, we show the producer's perspective on adopting biochar, using Polish farmers as a case study. Poland is an interesting case study because biochar has only recently attracted the attention of researchers, entrepreneurs, and other stakeholders there. We performed standardized, semi-structured interviews with 161 Polish farmers to evaluate the socioeconomic potential of biochar application in practice. We found that $27 \%$ of the respondents claimed to be familiar with biochar. The respondents with a technical, non-agricultural level of education were most familiar with the term 'biochar' (36\%), followed by the group of respondents with a higher-level agricultural education (31\%). It was surprising that among the latter respondents, the majority $(69 \%)$ did not know the term 'biochar', either in the context used for this study or in any other context. Twenty percent of the respondents expressed an interest in using biochar, while $43 \%$ were not willing to adopt it in their agricultural practice (37\% 'did not know yet'). If a farmer was familiar with the concept of sustainable agriculture, the probability of familiarity with biochar increased by $16 \%(p<0.05)$. In addition, farmers interested in using biochar indicated that sustainable agriculture might improve the financial situation of their farms (52\%). The perceived benefits of biochar that drive the willingness to adopt it included improved soil quality and increased income due to increased yields, while the constraints on its adoption were associated mainly with high costs. Our results also point to the necessity of information flow as well as engaging farmers in participatory research to adjust the research to their needs. Furthermore, our results highlight the importance of transparency with the farmers and appropriate dissemination and presentation of both the positive and the negative aspects of biochar adoption. We urge those studying biochar to engage in more interdisciplinary research and to go beyond laboratory and field research. Many innovations, even those that work, will not be adopted if socioeconomic considerations are not incorporated into the research.
\end{abstract}


Keywords: biochar; decision making; farming; social aspects; sustainable agriculture; Poland

\section{Introduction}

Biochar is a carbonized substrate that in recent years has increasingly attracted scientific attention [1]. Biochar is produced by thermal decomposition of biomass (such as crop residues) in an oxygen-limited environment called pyrolysis [1]. When added to soil, biochar can improve soil water-holding capacity [2-4], soil pH [5-7] and may be used in soil remediation [8]. While a significant amount of research has been conducted worldwide, a wider interest in and research into biochar have only recently been reported in countries such as Poland $[9,10]$. Among the countries where a number of biochar projects have been established, the United Kingdom, Germany and Finland lead research in Europe [11]. In Poland, the main aspects being researched are biochar's potential for soil bioremediation, its agricultural potential (Figure 1), and its potential for energy purposes. For instance, pilot studies were conducted on biochar use in the remediation of soils, collected near copper smelters in Poland, that were multi-contaminated by heavy metals. The results suggested that biochar made from wheat straw and miscanthus in $2 \%$ addition to the soil is highly effective in reducing the bioavailability of $\mathrm{Cu}, \mathrm{Zn}$ and $\mathrm{Pb}$ and the uptake by plants growing on highly contaminated soils [12].

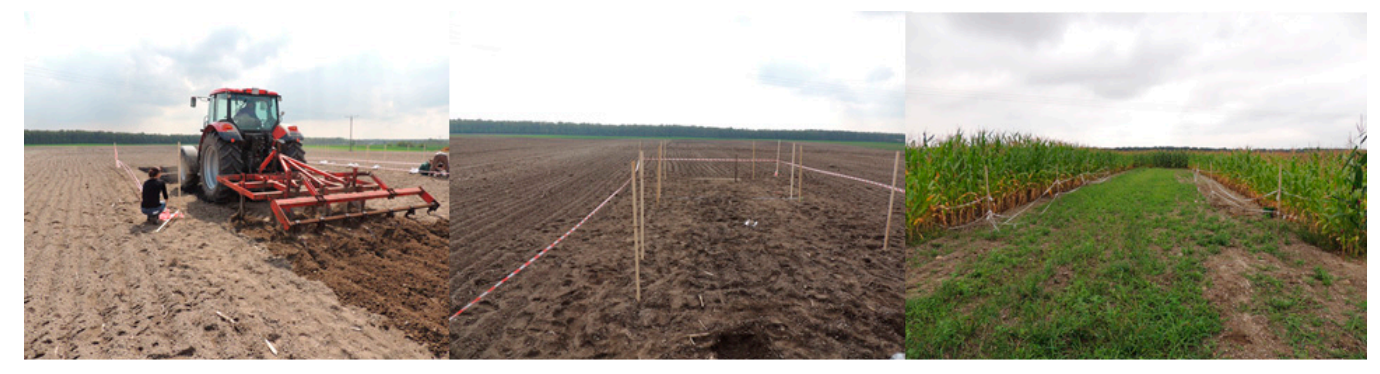

Figure 1. One of the first field experiments with biochar in Poland (biochar used for the experiments was provided by Fluid S.A. (Sędziszów, Poland). Maize and rapeseed were used as testing plants over three vegetative cycles between 2013 and 2016. Experiment coordinated by the Opole University of Technology in collaboration with Wroclaw University of Life Sciences and University of Agriculture in Kraków. Photos by Agnieszka Latawiec.

In addition, topics related to practical application of biochar has recently been taken up by several research institutions in Poland. For instance, in 2013 the Institute of Ceramics and Building Materials in Opole joined the international project entitled Environmental and Economic Benefits from biochar clusters (E2BEBIS) focused on the environmental and economic benefits resulting from the creation of biochar clusters in Central Europe (www.e2bebis.eu). The main objective of the project was to increase public awareness of the technology of production and application of biochar as a new 'green' product. Other research institutions such as Wroclaw University of Environmental and Life Sciences, Czestochowa University of Technology [2,12-18], Poznan University of Life Sciences [2,12,14,15,17], University of Life Sciences in Lublin [19] are also conducting research focused on biochar use. However, to date, most of the research in Poland has been related to the presentation of the 'current state of the art' and most of the published research is of a 'review' nature [2,12,14,20,21], although some of these institutions have long-term experience with biochar research (e.g., [13,15,18,19]). Although an increasing number of research and development projects from both research institutions and private companies is visible in Poland, most of this research is in preliminary stages when compared to the experience (counted as number of articles published) of Western Europe, the United States or Australia.

Considering biochar use in Poland is timely for other reasons. Poland is a major agricultural producer in Europe, and agricultural lands make up 50\% of its total land area. Poland is also a major 
exporter of agricultural products; for example, in 2013, it exported the highest quantity of apples in the world [22]. However, Polish agriculture is characterized by low productivity compared with that of western European countries, and there is potential to sustainably increase yields [23-25]. Such a strategy has been promoted in recent years by researchers and various organizations as a way to produce more from a limited area in an environmentally and socially responsible manner $[20,26]$. Biochar could therefore be a potential tool for sustainably increasing agricultural productivity in Poland, especially given the predominance of small to medium-sized farms (the average size of a farm in Poland is 10.38 hectares) [22]. The main crops cultivated in Poland are wheat and rye [22]; the productivity of these crops is below the sustainable potential [24], and there is a need to improve the adoption rate of new approaches aimed at increasing productivity while minimizing adverse environmental effects. The potential of biochar for carbon sequestration is also an interesting angle in Poland, particularly given the international pressure to diminish carbon emissions in a country with limited options [10].

The most commonly investigated aspects of biochar are the source of the biomass, the means of production, and whether and how it is applied to soil [1,27]. The social aspects, even though they are crucial for the ultimate adoption of biochar in agriculture, have been poorly reported. When considering the overall opportunities and risks of biochar systems, four factors must be taken into account: the impacts on soil health and agricultural productivity, the impacts on climate change, the competing uses of the biomass, and the social impacts [28]. Scholz and colleagues [28] described social impacts connected to biochar's appeal to energy efficiency, health, economics, and food security. Their findings indicated that the main barriers to implementing biochar in agricultural practice are social and cultural. Among the sociocultural barriers mentioned were people's resistance to new approaches to development, a lack of available biochar, a lack of technology for biochar production, a lack of information about the properties of biochar, and farmers' skepticism [28]. They highlighted the necessity of future research on the social aspects of biochar systems related to technology adoption.

Conte and colleagues [11] reviewed the main biochar research questions in Europe, and none of those questions focused on the social aspects. Bjerregaard [29] presented a comprehensive analysis of incorporating social research into the study of biochar as a new technology with a range of stakeholders in Denmark. Some of the potential barriers to farmers' adoption reported in the literature include the cost, lack of interest, and lack of trust that the results will be worth the investment.

To our knowledge, studies that involve farmers-who are key to adopting biochar in their practice-are scarce. Few studies consider farmers' perspectives on whether biochar is a potential alternative as a soil enhancer. However, literature shows that the adoption of agricultural technologies is a complex process, affected by a range of factors [4,30]. Financial and technological aspects of agricultural development have often been highlighted in the studies on the adoption of new tools, often omitting crucial social and cultural aspects that fundamentally govern the adoption of new tools and technologies [31]. In the case of biochar, the economic aspect of production and application in real-world systems is still under-researched [32,33]. Even though cost-benefit analyses from developed countries such as the USA or UK exist, they are focused on large-scale profit-making enterprises rather than the decision-making environment of smallholder farmers [34-36].

However, the producer's perspective is critical for the long-term success of any innovation. An example is a project to improve the fertility of soil formulations containing beneficial microorganisms. In that project, it was observed that in Poland, farmers with acreage below 100 ha were reluctant to implement technological innovations, while large-scale farmers showed much greater interest. This reluctance was related to the desire to limit production costs. Obviously, a small-scale farmer is less likely to spend financial resources on innovations because of the losses that may be incurred. These results, however, contradict situations observed in other countries. For example, in Brazil, small-scale farmers are more prone to adopt innovations because they gain more based on scale than do farmers with larger operations [6]. 
It has become increasingly clear that socioeconomic concerns cannot be overlooked if any initiative aimed at sustainable land management is to be successful in the long term. The producer's perspective is paramount to understanding how biochar may be applied in practice, and if biochar is to bring environmental and economic benefits, it must go beyond presenting promising results in laboratory research and be adopted at the individual farm scale. A range of innovations that have been shown to increase productivity, to be environmentally friendly, and to have other potential economic benefits to the farmer have not been adopted. Anecdotal evidence has shown that a lack of interest, saturation of the market, and price were among the reasons for market failure. Research into biochar in Poland is very limited and requires a deeper understanding of the environmental and socioeconomic impacts $[13,14,37]$.

The objective of this study is to report opportunities and constraints associated with the potential use of biochar as perceived by farmers in Poland. To this end, we performed semi-structured personal anonymous interviews with the farmers. The use of social research in the field of environmental protection allows for in-depth knowledge of people's positions regarding such environmental issues as sustainable agriculture and the use of biochar on the farm. More importantly, it helps us understand what courses of action should be followed in shaping environmental policy. Hence, there is a growing need for interdisciplinary research combining such seemingly disparate research areas as agricultural science and social science. The success of any attempt to implement better land management practices through the use of biochar may be undermined by the different priorities of the producers or other barriers that were not explored. In addition, incorporating biochar into a farmer's practice may require specialized knowledge and technical assistance. Unless these barriers are understood, reduced, or eliminated, a shift towards more productive agriculture based on biochar may be heavily constrained [38]. To our knowledge, this study is the first to look into the producer's perspective about biochar in Poland. We draw attention to the importance of this type of study in the overall field of biochar research.

\section{Methods}

\subsection{Literature Review}

The first stage of the study was the literature review, which was performed in English and in Polish. The script for the search included the words 'social aspects of adopting biochar', 'biochar AND decision making', 'biochar AND social acceptance', 'biochar AND adopting in agricultural practice', and 'biochar AND use in practice'. The literature search was conducted with search engines such as Google Scholar, Web of Science, and Scopus as well as through general Internet websites. Little information (and even less peer-reviewed material) was retrieved that dealt exclusively with the social aspects of the use of biochar.

\subsection{Survey}

To obtain information about farmers' perspectives on the adoption of biochar, we opted for anonymous, semi-structured personal interviews with the farmers. This approach was considered superior to other methods (e-mail questionnaires, focus groups, phone interviews) given the farmers' profile (the semi-structured interview gave them an opportunity to explain if something was not understood), increased response rate, and percentage of finished questionnaires.

The standardized questionnaire consisted of 20 questions divided into five parts: (i) information about the farm (e.g., location, type of husbandry, equipment used); (ii) perceptions about sustainable agriculture (understanding and implementation of sustainable agriculture, practice of environmental restoration); (iii) waste management (type and volume of organic and nonorganic waste production at the farm, utilization of management practices); (iv) biochar (familiarity with the concept of biochar, interest in biochar, willingness to adopt biochar in the farm practice, potential biochar production), and (v) personal data (e.g., age, education, source of income). A copy of the questionnaire is included in the Supplementary Materials. 
The questionnaire was formulated in non-scientific language. While undergoing interviews, the respondents could ask for clarification, which would be given in nontechnical language. Given that the term 'biochar' can be used in other contexts, we gave a definition of biochar (Box 1) and provided further clarification whenever necessary to assure that the respondent's meaning aligned with that of the interviewer. The development of the questionnaire followed consultations with a range of researchers and technicians to ensure that the questions would be understood by the farmers. A pilot study was performed with seven farmers, after which further clarifications were incorporated into the full study.

Box 1. Definition of biochar as given in the questionnaire.

Biochar-char that is produced during the combustion of organic residues. Biochar is produced in special stoves at temperatures above $300^{\circ} \mathrm{C}$ with little air. There is a large amount of biomass residue needed to produce substantial amounts of biochar. Biochar may be used in agriculture to improve soil $\mathrm{pH}$, sorption properties, organic matter content and soil fertility. Biochar therefore may improve yields on poor and degraded soils. Biochar can also be used for energy production, bioremediation and carbon sequestration in soil.

\subsection{Study Side and Profile of Respondents}

Two principal provinces out of sixteen in Poland were chosen for this research. The provinces Opolskie and Małopolskie were chosen for a number of reasons. Both are agricultural areas; Opolskie is characterized by modern, increasingly large-scale agriculture, and Małopolskie has a significant proportion of small-scale farmers. There is an established relationship between the researchers and the farmers; therefore, the credibility of the responses can be assumed to be high. We performed 161 interviews with farmers in 2014 (selected by opportunistic sampling). A small number of interviews was also conducted with respondents from other provinces: Wielkopolskie $(n=5)$, Slaskie $(n=1)$, and Lodzkie $(n=1)$; however, the majority of the interviews occurred in Małopolskie $(n=80)$ and Opolskie $(n=74)$. The majority of the respondents had a technical education (agricultural-19\%,n=31; non-agricultural-17\%,n=28) or secondary education (agricultural-22\%, $n=36$; non-agricultural-14\%, $n=22$ ). Figure 2 shows the survey area and selected descriptive statistics.
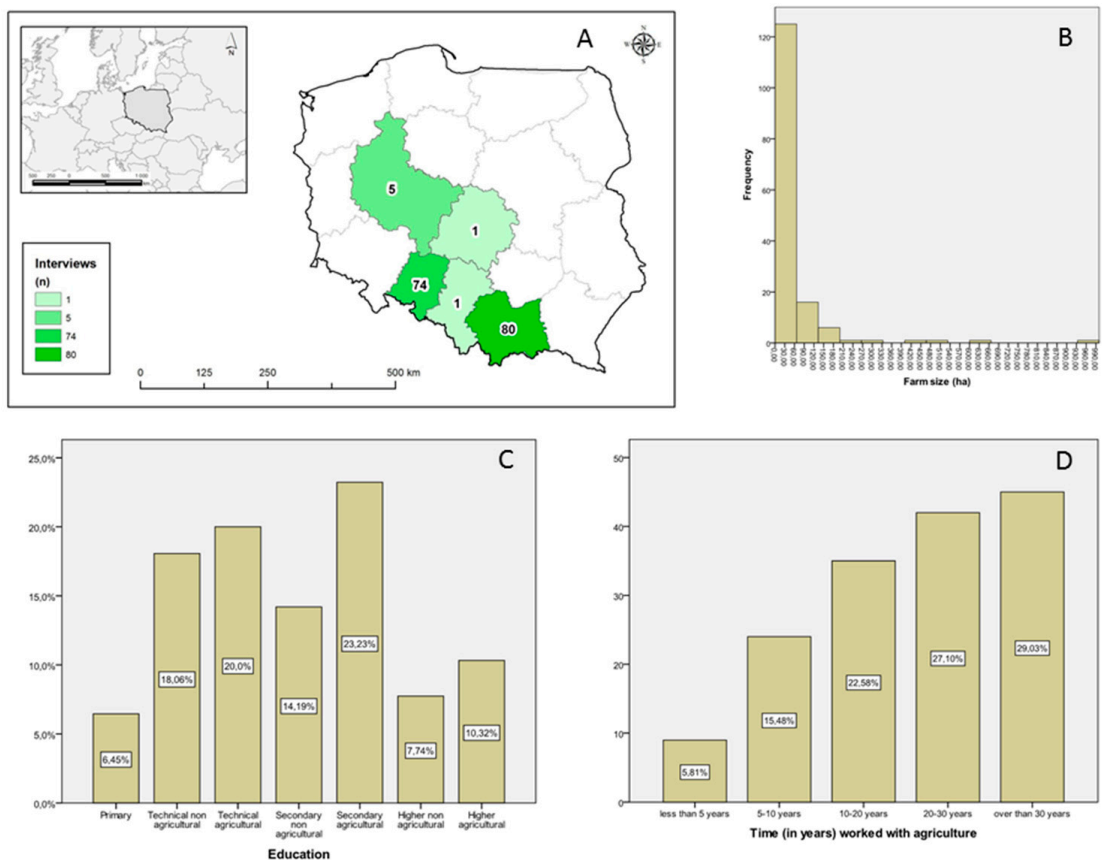

Figure 2. Survey area and selected descriptive statistics. (A) Survey area (Małopolskie $(n=80)$; Opolskie $(n=74)$; Wielkopolskie $(n=5)$; Slaskie $(n=1)$; Lodzkie $(n=1)) ;($ B) Farm size of the respondents; (C) Education level of the respondents; (D) Time (in years) worked with agriculture. 


\subsection{Follow-Up Interviews}

During the analysis of the results from the questionnaire, a number of questions were raised. For example, (i) Why would the farmers be (or not be) interested in adopting biochar in their practice? (ii) Where does their knowledge about biochar come from? (iii) What are the perceived benefits and limitations associated with the use of biochar? Therefore, we performed follow-up semi-structured interviews using the PAPI (paper-and-pencil interviewing) method during a conference for the farmers $(n=51)$.

\subsection{Data Processing}

The results from the interviews were transcribed into Excel and imported into the SPSS (IBM SPSS Statistics 23 for Windows, Armonk, NY, USA) for statistical data processing. Other statistical analyses included a log-linear analysis (probit and logit) to identify the correlation among socioeconomic variables (education, age, source of income, etc.) and the adoption of biochar (familiarity with the concept, willingness to adopt, etc.). Probit and logit analyses were performed using the R software package (R Core Team, Vienna, Austria, 2013). We also performed probit analysis to investigate which factors increased the probability that the farmer was familiar with biochar. Log-linear analyses assume that the observations are independent and random and that they can indicate correlations among several categorical variables. The results presented here are from a case study and do not have a representative character.

\section{Results and Discussion}

\subsection{Familiarity with Biochar}

Approximately one-third $(27 \%, n=44$; Table 1$)$ of the respondents claimed to be familiar with biochar. The probability that the respondents would know about biochar is $26 \%$ (Figure 3).

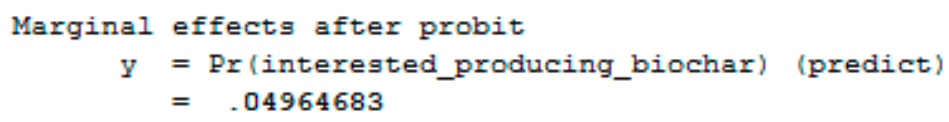

\begin{tabular}{|c|c|c|c|c|c|c|c|}
\hline variable & $\mathrm{dy} / \mathrm{dx}$ & Std. Brr. & $\mathbf{z}$ & $\mathrm{P}>|z|$ & 958 & C.I. & $\mathrm{x}$ \\
\hline know_b r ${ }^{+}$ & .0261139 & .04328 & 0.60 & 0.546 & -.058712 & .11094 & .272152 \\
\hline$i \sim u g i n \sim r^{*}$ & .1859353 & .0816 & 2.28 & 0.023 & .026005 & .345866 & .196203 \\
\hline know_g g ${ }^{*}$ & .0652139 & .03075 & 2.12 & 0.034 & .004952 & .125476 & .721519 \\
\hline
\end{tabular}

(*) dy/dx is for discrete change of dumy variable from 0 to 1

Figure 3. The results of probit modeling for familiarity with biochar and willingness to apply it in agricultural practice.

These results are somewhat surprising. Bjerregaard [29] showed that only $5 \%$ of Danish farmers had heard of biochar. We stipulate that the difference between those results and ours may be due to different methodologies. In our study, the definition of biochar was given so the farmer could clearly understand the meaning. In addition, Bjerregaard's [29] results relied on interviews not only with the farmers but also with a range of stakeholders whose opinions might have differed significantly from those of the farmers [10,39]. Additionally, our research was conducted a few years later, when the term 'biochar' had been known longer (although its use was relatively more recent in Poland). Finally, the farmers in Poland may have overestimated their familiarity with the term. 
Table 1. Familiarity with the term biochar.

\begin{tabular}{ccc}
\hline Familiarity with Biochar & N & $\mathbf{\%}$ \\
\hline Yes & 44 & 27 \\
No & 116 & 72 \\
Total & 160 & 99 \\
Lack of data & 1 & 0.6 \\
Total & 161 & 100 \\
\hline
\end{tabular}

The respondents from Małopolska province were more familiar with the term 'biochar' than those from Opolskie province (32\% versus 25\%). If a respondent was from the Małopolska province, the probability of him or her knowing the term biochar increased by $15 \%(p>0.05$, but $p<0.1$; see the Supplementary Materials). We also observed an interesting correlation between the level of education and familiarity with the term. The term was best known among the group of respondents with a technical non-agricultural education (36\%), followed by the group of respondents with a higher-level agricultural education (31\%). It was surprising that the majority of the respondents $(69 \%)$ among those with a higher-level agricultural education did not know the term, neither in the context used for this study nor in any other context (We asked whether the term biochar was known as given by us or in any other context as the term can be confused with charcoal or peat.). The highest level of familiarity with biochar was observed in the group of respondents who have run agricultural businesses for 10-20 years $(40 \%)$, while the lowest level was in those who have run agricultural businesses for $5-10$ years (17\%; Table 2$)$.

Table 2. Familiarity with the term biochar versus time of running the agricultural business.

\begin{tabular}{ccccc}
\hline \multirow{2}{*}{} & & \multicolumn{2}{c}{ Familiarity with Biochar } & \multirow{2}{*}{ Total } \\
\cline { 3 - 4 } & & Yes & No & \\
\hline \multirow{2}{*}{ Less than 5 years } & $\mathrm{N}$ & 2 & 7 & 9 \\
& $\%$ & $22 \%$ & $78 \%$ & $100 \%$ \\
\hline \multirow{2}{*}{$5-10$ years } & $\mathrm{N}$ & 4 & 19 & 23 \\
& $\%$ & $17 \%$ & $83 \%$ & $100 \%$ \\
\hline \multirow{2}{*}{$10-20$ years } & $\mathrm{N}$ & 14 & 21 & 35 \\
& $\%$ & $40 \%$ & $60 \%$ & $100 \%$ \\
\hline \multirow{2}{*}{$20-30$ years } & $\mathrm{N}$ & 14 & 28 & 42 \\
& $\%$ & $33 \%$ & $67 \%$ & $100 \%$ \\
\hline \multirow{2}{*}{ More than 30 years } & $\mathrm{N}$ & 8 & 37 & 45 \\
& $\%$ & $18 \%$ & $82 \%$ & $100 \%$ \\
\hline
\end{tabular}

\subsection{Willingness to Adopt Biochar in Agricultural Practice}

Familiarity with the term 'biochar' may have consequences for the level of interest in applying it in practice. One in five of the respondents $(20 \%)$ expressed interest in using biochar. This finding is not surprising, given the early stage of familiarity with biochar. Some authors claim that if biochar becomes officially recognized as a tool for carbon soil sequestration (a goal of the International Biochar Initiative), and/or if farmers adopt biochar as part of their practice, it is likely that it will become a popular tool [29]. In Bjerregard's [29] study, this suggestion is supported by the other social groups' indications that they would quickly become involved in the use of biochar if these barriers were overcome.

In our study, $43 \%$ were not willing to adopt biochar in their practice, while 37\% 'did not know yet'. As the question was open-that is, we deliberately did not provide possible answers-the respondents indicated various reasons to apply or not apply biochar, and there was no single dominant motive. Although not everybody answered the question (those respondents who indicated that they were not familiar with biochar did not answer it), some repeated reasons to use biochar were benefits for plants and animals, the ability to improve yields, the desire to care for the environment and human health, 
poor soil and the desire to improve it, the desire to improve low $\mathrm{pH}$, and interest in new energy sources. By contrast, aversion to the use of biochar was supported by lack of access, costs, a feeling that the farm was too small, lack of opportunities, preference for other methods, and the use of biotechnology. A complete list of answers can be found in the Supplementary Materials.

The willingness to adopt biochar was higher in Małopolskie (22\%) than in Opolskie (15\%), corroborating our interpretation that familiarity with biochar impacts the willingness to adopt it. The cross-analysis of data on the level of knowledge and the willingness to use biochar confirms this argument. Among the respondents who had heard of biochar, 39\% were interested in using it, 39\% were not interested in using it, and 21\% answered, 'I do not know yet'. However, in a group of people who had not yet heard about biochar, only $12 \%$ were interested in using it, $44 \%$ were not interested, and $43 \%$ answered, 'I do not know yet'. This result confirms the argument for the direct relationship between the knowledge of biochar and willingness to use it.

The willingness to adopt biochar is also dependent on how long the farmer has run his or her agricultural practice. We found that the farmers that run their agricultural businesses between 5 and 10 years are the most interested in adopting biochar within their farm activities (Table 3). The farmers who have run their agricultural businesses for longer periods may be more conservative and may have set ways of running their farms, while people who have recently entered the business may be more open to innovations [10].

Table 3. The willingness to adopt biochar versus time of running the agricultural business.

\begin{tabular}{cccccc}
\hline \multirow{2}{*}{$\begin{array}{c}\text { Time of Running the } \\
\text { Agricultural Business }\end{array}$} & \multicolumn{2}{c}{$\begin{array}{c}\text { I Am Interested in Applying } \\
\text { Biochar within My Farm Activities }\end{array}$} & \multirow{2}{*}{ Total } \\
\cline { 2 - 5 } & & Yes & No & I Do Not Know & \\
\hline \multirow{2}{*}{ Less than 5 years } & $\mathrm{N}$ & 2 & 2 & 5 & 9 \\
& $\%$ & $22 \%$ & $22 \%$ & $56 \%$ & $100 \%$ \\
\hline \multirow{2}{*}{$5-10$ years } & $\mathrm{N}$ & 6 & 9 & 8 & 23 \\
& $\%$ & $26 \%$ & $39 \%$ & $35 \%$ & $100 \%$ \\
\hline \multirow{2}{*}{$10-20$ years } & $\mathrm{N}$ & 7 & 14 & 13 & 34 \\
& $\%$ & $21 \%$ & $41 \%$ & $38 \%$ & $100 \%$ \\
\hline \multirow{2}{*}{$20-30$ years } & $\mathrm{N}$ & 8 & 19 & 15 & 42 \\
& $\%$ & $19 \%$ & $45 \%$ & $16 \%$ & $100 \%$ \\
\hline \multirow{2}{*}{ More than 30 years } & $\mathrm{N}$ & 8 & 20 & $38 \%$ & 45 \\
& $\%$ & $18 \%$ & $44 \%$ & 58 & $100 \%$ \\
\hline \multirow{2}{*}{ total } & $\mathrm{N}$ & 31 & 64 & $38 \%$ & 153 \\
& $\%$ & $20 \%$ & $42 \%$ & $100 \%$ \\
\hline
\end{tabular}

Among those respondents who wanted to apply biochar, 55\% declared that they had some knowledge about it. In the case of those who disliked the idea or answered, 'I do not know yet', the lack of knowledge about biochar predominated (respectively, 75\%, $n=51$, and 85\%, $n=50$ ). The same tendency was confirmed in the relationship between the willingness to use biochar and knowledge about the concept of sustainable agriculture. Among those respondents who were willing to use biochar, the level of knowledge about the concept of sustainable agriculture was approximately $74 \%(n=23)$, whereas among those rejecting such a possibility, the level of knowledge about sustainable agriculture was $66 \%(n=4)$. Indeed, if a farmer is familiar with the concept of sustainable agriculture, the probability of his or her being familiar with biochar increases by $16 \%(p<0.05$; Figure 4$)$. We therefore anticipate that the willingness to adopt biochar is related to knowledge about it. 


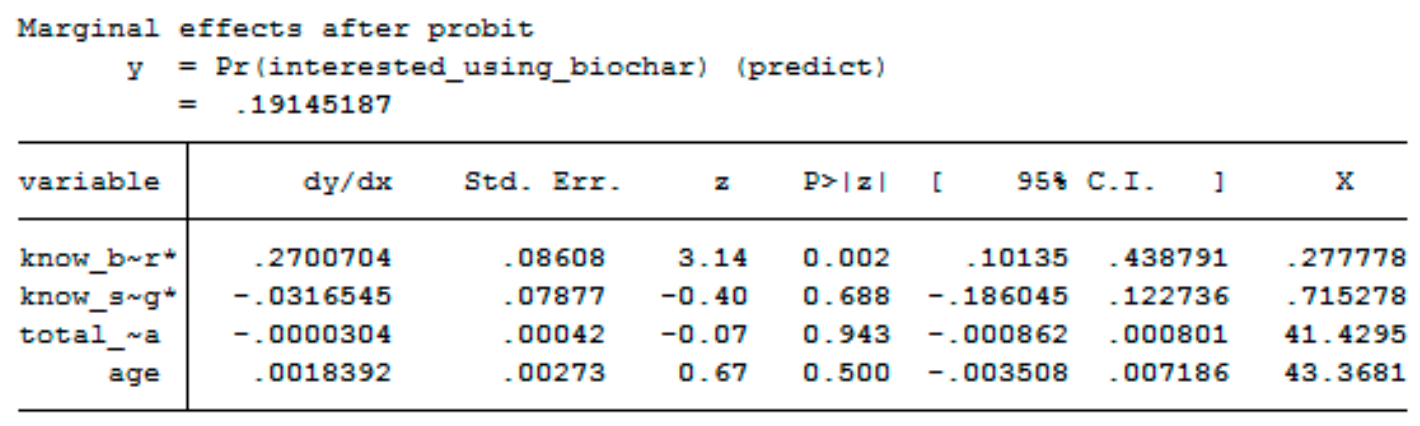

(*) $\mathrm{dy} / \mathrm{dx}$ is for discrete change of dumy variable from 0 to 1

Figure 4. The results of probit modelling for being familiar with biochar and being familiar with the concept of sustainable agriculture (explanation in text).

One of the questions was about whether the concept of sustainable agriculture was an opportunity to improve the profitability of farms. The answer 'yes' was indicated by $34 \%(n=54)$ of the respondents, 'no' by $18 \%(n=28)$, and 'I do not know' by approximately $48 \%(n=75)$. Farmers interested in using biochar also indicated that sustainable agriculture might improve the financial situation of the farm $(52 \%)$. Willingness to adopt biochar was also related to the perception of the farmer regarding whether sustainable agriculture might improve the rentability of the farm. Farmers who were not interested in adopting biochar, or who answered 'I do not know', were mostly unable to specify whether sustainable agriculture could improve their financial situation. This result is not surprising. Biochar may be associated with the idea of 'pro-ecological solutions', and a farmer who considers that sustainable agriculture has a positive effect on the farm's finances may be more willing to adopt biochar. Therefore, the economic aspect of the use of biochar or any other technique is extremely important. However, the use of biochar may have more than economic benefits (carbon sequestration, etc.); some farmers may be more environmentally-conscious and will want to adopt it for those reasons. Some farmers in Poland take a highly pragmatic approach to sustainable management of their farms [40]. Even though seemingly not in favour of environmental management, they do not overuse pesticides and other potentially harmful substances merely to minimize the costs.

Few farmers $(8 \%)$ were interested in producing biochar, and the probability that a respondent would be willing to produce biochar was very small (5\%; Supplementary Materials). Sixty percent of the respondents were not interested in producing biochar; however, 30\% answered, 'maybe'. We also found interesting statistically significant differences between willingness to produce biochar and other variables. If the farmer had an interest in using biochar, the probability of willingness to produce biochar increased significantly by $19 \%$ (Supplementary Materials). If the farmer was familiar with the concept of sustainable agriculture, the chance of willingness to produce biochar increased by $6 \%$.

The respondents who were interested in biochar production indicated slurry, forestry residues, straw, power plants and wood waste as potential sources of residues for producing biochar. The most frequently mentioned potential source was straw (mentioned 7 times). It was not possible to note any significant relationship between willingness to use biochar on a farm and the amount of waste produced on the farm, because the willingness to use biochar was indicated by farmers producing a small amount of waste (20-120 t/year), the average amount (800 t/year), and a huge amount (40,000 $\mathrm{t} /$ year). However, in the case of interest in biochar production and the level of waste produced, the willingness expressed by farmers was highest among those who produced at least $500 \mathrm{t} /$ year of organic waste. However, we must remember that there were not many positive answers. The level of interest in biochar production in cooperation with other producers was at a level similar to that of interest in producing it on their own farms: $7 \%$ of the respondents were interested, $55 \%$ lacked interest, and $38 \%$ answered, 'maybe'.

In response to the question regarding the problems faced by farmers in everyday practice, lack of funds was the most frequent answer (lack of money for better equipment- $53 \%$ and lack of money 
to improve the soil conditions-43\%). In general, Polish agriculture is overinvested compared with agriculture in other European countries. Every farmer wishes to have his or her own tractors and other equipment, even when such items could be shared, which might be better from an economic point of view [20]. Other responses indicated the problem of soil quality resulting from its low value $(42 \%)$ and acidification (38\%). Less frequent answers were soil retention-either too much or too little $(29 \%)$, low humus content in the soil $(28 \%)$, and technical infrastructure issues $(19 \%)$. Respondents could indicate any other issues, which 12 of them did. The most common problem was damage caused by forest animals ( 5 responses); others were too much fragmentation of the fields ( 2 responses), lack of drainage, inconsistent laws, and outlet problems. In addition, the problem of soil acidification seems to be an insufficient argument for convincing farmers to use biochar. Among the respondents who indicated soil acidification as a problem, $24 \%$ would be interested in using biochar, $35 \%$ were not interested, and 37\% answered, 'I do not know yet'.

There is little information about the propensity of farmers to adopt biochar. Research has focused instead on analyses of biochar's appropriateness for adoption. Such an assay has been conducted, for example, with a small group of respondents on the island of Haiti [41]. One aim of this study was to determine the appropriateness of biochar pyrolysis technology to increase crop yields and improve soil health. Data were collected based on 30 individual interviews and three focus groups. Delaney [41] presented key factors in the successful adoption of biochar use, such as education about biochar and a variety of pyrolysis technology options among which villagers could choose. An action-oriented plan was developed for use by development organizations, communities, and governmental institutions to increase the likelihood of adoption.

Clare et al. [32] investigated farmer perspectives on biochar in four contrasting Chinese agricultural systems, using linear optimization models and qualitative contextual data. Their assessment demonstrates that biochar research in China should shift away from on-farm production and use of pure biochar towards combined biochar-inorganic fertilizers and that commercially produced biochar is uneconomic as an independent farming input [32].

Biochar solutions should be addressed to specific situations. The implementation of biochar systems requires a highly location-specific understanding of people and their needs, values, and expectations. Certain sociocultural barriers to the adoption of biochar projects that were identified in a survey [42] included lack of awareness of biochar and a need for education and demonstration projects to show farmers that making and using biochar would be worth their time and labour despite the restricted availability of biochar production technologies and environmental concerns related to changing resource use patterns.

\subsection{What Drives Farmers' Interest in Adopting Biochar?}

The follow-up study of the drivers of interest in biochar was performed with 51 farmers. We confirmed that familiarity with biochar is related to the interest in applying it at an individual farm. Sixty-seven percent of the respondents claimed to be familiar with biochar, and $35 \%$ were interested in using it on their farms. Regarding the sources of this knowledge, the conference about biochar proved to be the major source of information (53\%). Eight percent mentioned articles related to alternative energy sources and $6 \%$ of the respondents referred to the Internet. However, no information about biochar had been acquired from media (such as television, radio, or magazines), training courses, or any instructional material related to biomass utilization. Among the respondents who had received information about biochar during the specialized conference, 59\% were interested in its use. Showing both the positive and negative sides of using biochar (as presented during the conference), had seemingly convinced most of those respondents to consider biochar application in practice.

Among the respondents, the vast majority had a very positive attitude towards ecology. For $74 \%$ of the respondents, ecology is very important; for $22 \%$, it is important. Only $4 \%$ of respondents have an indifferent attitude to ecology, and no one from the surveyed people revealed that this issue is not important. The correlation between a positive attitude towards ecology and willingness to 
use biochar shows that the better the attitude towards ecology, the greater the willingness to use biochar, which confirms our previous conclusions regarding sustainable agriculture. In addition, among the respondents declaring that ecology is very important, $42 \%$ were willing to use biochar and $58 \%$ declared reluctance, while among the respondents declaring that ecology is important, $18 \%$ would apply biochar and $82 \%$ would not.

Regarding the question about benefits and the concerns associated with the use of biochar, the greatest benefit indicated by the respondents was improving the soil quality $(50 \%)$. In turn, the greatest concerns were related to the cost $(52 \%)$ and the uncertainty whether biochar will work $(26 \%)$.

\section{Conclusions}

Knowledge of the social aspects of biochar is essential if biochar is to be adopted in agricultural practice in Poland and elsewhere. However, little attention has been paid to this aspect of biochar research. We present here the results of the first study in Poland, and one of the first in Europe, of the factors that affect farmers' propensity to adopt biochar as well as its possible consequences for sustainable management of their farms. We also discuss other implications for more sustainable agriculture. Our results suggest that the probability of using biochar is $19 \%$, and it increases to $27 \%$ if the farmer is familiar with biochar. We also observed that it is important to present both the positive and the possible negative consequences of biochar application in soil, as was done at the thematic conference with the farmers, because this approach increases the farmers' confidence in the information. The results of this research therefore distinctly show a relationship between knowledge about biochar and the willingness to use it. The size of the farm, the amount of organic waste produced, the level of education, and the age of the respondents does not affect the potential use of biochar.

The main argument in favor of biochar indicated by the respondents was the improvement of soil quality, while the main concern was the cost. It is of the utmost importance to include this kind of research in the overall agenda of biochar research, as the utility of biochar in agriculture ultimately depends on the willingness of the farmer to adopt it in practice.

Supplementary Materials: The following are available online at www.mdpi.com/2071-1050/9/4/655/s1, Section S1: Semi-structured interviews, Section S2: Probit and logit analyses, Section S3: Follow-up questionnaire.

Acknowledgments: We thank all the respondents that took part in the interviews. Rafael Feltran is gratefully acknowledged for his help on statistical analyses. Katarzyna Korys is gratefully acknowledged for her help on the manuscript formatting. We thank Izba Rolnicza in Opole for conference preparation.

Author Contributions: A.E.L. conceived and designed the study. J.B.K., M.K., K.S., A.D. revised the questionnaire and the follow up questionnaire drafts. J.B.K., M.K., K.S., E.P. performed the interviews; A.E.L., J.B.K., M.K., A.D., B.B.N.S., K.G. analyzed the data; A.E.L., J.B.K., K.G., M.K., A.D., K.S., B.B.N.S. wrote the paper.

Conflicts of Interest: The authors declare no conflict of interest.

\section{References and Notes}

1. Lehmann, J.; Joseph, S. Biochar for Environmental Management: Science and Technology; Routledge: Abingdon, UK, 2012.

2. Peake, L.; Freddo, A.; Reid, B.J. Sustaining soils and mitigating climate change using biochar. Sustain. Sci. Technol. 2014. [CrossRef]

3. Haider, G.; Steffens, D.; Moser, G.; Müller, C.; Kammann, C.I. Biochar reduced nitrate leaching and improved soil moisture content without yield improvements in a four-year field study. Agric. Ecosyst. Environ. 2017, 237, 80-94. [CrossRef]

4. Vanclay, F. Social principles for agricultural extension to assist in the promotion of natural resource management. Aust. J. Exp. Agric. 2004, 44, 213-222. [CrossRef]

5. Laird, D.A.; Fleming, P.; Davis, D.D.; Horton, R.; Wang, B.; Karlen, D.L. Impact of biochar amendments on the quality of a typical Midwestern agricultural soil. Geoderma 2010, 158, 443-449. [CrossRef] 
6. Latawiec, A.E.; Strassburg, B.B.N.; Silva, D.; Alves-Pinto, H.N.; Feltran-Barbieri, R.; Castro, A.; Iribarrem, A.; Rangel, M.C.; Kalif, K.A.; Gardner, T.; et al. Improving land management in Brazil: A perspective from producers. Agric. Ecosyst. Environ. 2017, 240, 276-286. [CrossRef]

7. Rasul, F.; Ahmad, A.; Arif, M.; Mian, I.A.; Ali, K.; Qayyum, M.F.; Hussain, Q.; Aon, M.; Latif, S.; Sakrabani, R.; et al. Biochar for Agriculture in Pakistan. Sustain. Agric. Rev. 2017, 22, 57-113.

8. Hale, S.E.; Elmquist, M.; Brändli, R.; Hartnik, T.; Jakob, L.; Henriksen, T.; Werner, D.; Cornelissen, G. Activated carbon amendment to sequester PAHs in contaminated soil: A lysimeter field trial. Chemosphere 2012, 87, 177-184. [CrossRef] [PubMed]

9. Handzel, A.; Królczyk, J.B.; Latawiec, A.E.; Pluta, K.; Malina, D.; Sobczak-Kupiec, A. Analiza właściwości fizykochemicznych gleb i oznaczanie zawartości wybranych pierwiastków. Infrastrukt. Ekol. Teren. Wiej. 2017, I/2, 419-432.

10. Latawiec, A.E.; Peake, L.; Baxter, H.; Cornelissen, G.; Grotkiewicz, K.; Hale, S.; Krolczyk, J.B.; Kubon, M.; Lopatka, A.; Medynska-Juraszek, A.; et al. A reconnaissance-scale GIS-based multicriteria decision analysis to support sustainable biochar use: Poland as a case study. J. Environ. Eng. Landsc. Manag. 2017, under review.

11. Conte, P.; Schmidt, H.P.; Cimò, G. Research and application of biochar in Europe. In Agricultural and Environmental Applications of Biochar: Advances and Barriers; Soil Science Society of America, Inc.: Fitchburg, WI, USA, 2016; pp. 409-422. [CrossRef]

12. Medyńska-Juraszek, A. Research report 2. INoGiOŚ 2014.

13. Bis, Z. Biowęgiel—Powrót do przeszłości, szansa dla przyszłości. Czysta Energia 2012, 6, 28-31.

14. Radawiec, W.; Dubicki, M.; Karwowska, A.; Żelazna, K.; Gołaszewski, J. Biochar from a digestate as an energy product and soil improver. Agric. Eng. 2014, 18, 149-156.

15. Czekała, W.; Malińska, K.; Cáceres, R.; Janczak, D.; Dach, J.; Lewicki, A. Co-composting of poultry manure mixtures amended with biochar-The effect of biochar on temperature and $\mathrm{C}-\mathrm{CO}_{2}$ emission. Bioresour. Technol. 2016, 200, 921-927. [CrossRef] [PubMed]

16. Malińska, K.; Golańska, M.; Caceres, R.; Rorat, A.; Weisser, P.; Ślęzak, E. Biochar amendment for integrated composting and vermicomposting of sewage sludge-The effect of biochar on the activity of Eisenia fetida and the obtained vermicompost. Bioresource Technol. 2017, 225, 206-214. [CrossRef] [PubMed]

17. Malińska, K.; Zabochnicka-Świątek, M.; Dach, J. Effects of biochar amendment on ammonia emission during composting of sewage sludge. Ecol. Eng. 2014, 71, 474-478. [CrossRef]

18. Malińska, K.; Zabochnicka-Świątek, M.; Cáceres, R.; Marfà, O. The effect of precomposted sewage sludge mixture amended with biochar on the growth and reproduction of Eisenia fetida during laboratory vermicomposting. Ecol. Eng. 2016, 90,35-41. [CrossRef]

19. Bogusz, A.; Oleszczuk, P. Phytotoxicity of biochars after the adsorption of heavy metals. In $V$ Krajowa Konferencja Bioindykacyjna "Praktyczne Wykorzystanie Systemów Bioindykacyjnych do Oceny Jakości i Toksyczności Środowiska i Substancji Chemicznych"; Seidel Przywecki: Józefosław, Poland, 2015. (In Polish)

20. Zawadzka, D.; Szafraniec-Siluta, E. Kapitałochłonność a stopa inwestycji gospodarstw rolnych w Polsce na tle krajów UE. Stow. Ekon. Rol. Agrobiz. 2015, 17, 353-360.

21. Malińska, K. Biowęgiel odpowiedzią na aktualne problemy ochrony środowiska. Inżynieria Ochrona Środowiska 2012, 15, 387-403. (In Polish)

22. Central Statistical Office. Statistical Yearbook of Agriculture; Central Statistical Office: Warsaw, Poland, 2013; ISSN: 2080-8798.

23. Grotkiewicz, K.; Michałek, R.; Kuboń, M.; Peszek, A. Postęp Naukowo-Techniczny w Procesie Modernizacji Polskiego Rolnictwa i Obszarów Wiejskich; Polish Society of Agricultural Engineering in Krakow: Kraków, Poland, 2013; ISBN: 978-83-935020-5-9. (In Polish)

24. Królczyk, J.B.; Latawiec, A.E.; Kuboń, M. Sustainable Agriculture-the Potential to Increase Wheat and Rapeseed Yields in Poland. Pol. J. Environ. Stud. 2014, 23, 663-672.

25. Michałek, R.; Grotkiewicz, K. Miejsce i rola postępu naukowego w warunkach rolnictwa zrównoważonego. Problemy Inżynierii Rolniczej 2010, 1, 1-8.

26. Foresight. The Future of Food and Farming; Final Project Report; The Government Office for Science: London, UK, 2011.

27. Shih-Hao, J.; Chung-Chi, W.; Chia-Hsing, L.; Tsung-Yu, L. Stabilization of Organic Matter by Biochar Application in Compost-amended Soils with Contrasting pH Values and Textures. Sustainability 2015, 7, 13317-13333. 
28. Shackley, S.; Ruysschaert, G.; Zwart, K.; Glaser, B. Biochar in European Soils and Agriculture; Routledge: London, UK; New York, NY, USA, 2016.

29. Bjerregaard, P.P.; Georg, S. The Social Shaping of Technology_A Case Study of Biochar in Denmark. 2011. Available online: http://studenttheses.cbs.dk/bitstream/handle/10417/1766/peter_poul_bjerregaard.pdf? sequence $=1$ (accessed on 5 January 2016).

30. Edward-Jones, G. Modelling farmer decision-making: Concepts, progress and challenges. Anim. Sci. 2006, 82, 783-790. [CrossRef]

31. Thompson, J.; Scoones, I. Addressing the dynamics of agri-food systems: An emerging agenda for social science research. Environ. Sci. Policy 2009, 12, 386-397. [CrossRef]

32. Clare, A.; Barnes, A.; McDonagh, J.; Shackley, S. From rhetoric to reality: Farmer perspectives on the economic potential of biochar in China. Int. J. Agric. Sustain. 2014, 12, 440-458. [CrossRef]

33. Clare, A.; Shackley, S.; Joseph, S.; Hammond, J.; Pan, G.; Bloom, A. Competing uses for China's straw: The economic and carbon abatement potential of biochar. Gcb Bioenergy 2015, 7, 1272-1282. [CrossRef]

34. Brown, T.R.; Wright, M.M.; Brown, R.C. Estimating profitability of two biochar production scenarios: Slow pyrolysis vs fast pyrolysis. Soc. Chem. Ind. 2010, 5, 54-68. [CrossRef]

35. Roberts, K.G.; Gloy, B.A.; Joseph, S.; Scott, N.R.; Lehmann, J. Life cycle assessment of biochar systems: Estimating the energetic, economic, and climate change potential. Environ. Sci. Technol. 2010, 44, 827-833. [CrossRef] [PubMed]

36. Shackley, S.; Hammond, J.; Gaunt, J.; Ibarrola, R. The feasibility and costs of biochar deployment in the UK. Carbon Manag. 2011, 2, 335-356. [CrossRef]

37. Malińska, K. Prawne i jakościowe aspekty dotyczące wymagań dla biowegla. Inżynieria Ochrona Środowiska 2015, 18, 359-371. (In Polish)

38. Smith, P.; Gregory, P.J.; van Vuuren, D.; Obersteiner, M.; Havlik, P.; Rounsevell, M.; Woods, J.; Stehfest, E.; Bellarby, J. Competition for land. Philos. Trans. R. Soc. B 2010, 365, 2941-2957. [CrossRef] [PubMed]

39. Halbrendt, J.; Gray, S.A.; Crow, S.; Radovich, T.; Kimura, A.H.; Tamang, B.B. Differences in farmer and expert beliefs and the perceived impacts of conservation agriculture. Glob. Environ. Chang. 2014, 28, 50-62. [CrossRef]

40. Królczyk, J.B.; Latawiec, A.E. Sustainability indicators for agriculture in the European Union. In Sustainability Indicators; Latawiec, A., Agol, D., Eds.; DeGruyter: Warsaw, Poland; Berlin, Germany, 2015; pp. 182-204.

41. Delaney, M.R. An Analysis of Biochar's Appropriateness and Strategic Action Plan for Its Adoption and Diffusion in a High Poverty Context: The Case of Central Haiti; Arizona State University: Phoenix, AZ, USA, 2011.

42. GreenFacts. Biochar Systems Using Biomass as an Energy Source for Developing Countries. Available online: http:/ / www.greenfacts.org/en/biochar/1-2/index.htm\#0 (accessed on 3 July 2015). 